\title{
MANAGEMENT OF MISALIGNED CROWN FRACTURE WITH EXTERNAL ROOF RESORPTION USING MINERAL TRIOXIDE AGGREGATE (MTA) AND CUSTOM CAST POST AND CORE RESTORATION
}

\author{
Rebecca Azary Kuncoro dan Yulita Kristanti \\ Conservative Dentistry Resident- Faculty of Dentistry \\ Universitas Gadjah Mada \\ Email: rebecca.kuncoro@yahoo.com
}

\begin{abstract}
ABSTRAK
Crown fracture adalah luka traumatis yang paling banyak dilaporkan terjadi pada gigi permanen. Salah satu respon yang tidak menguntungkan terhadap trauma adalah perkembangan resorpsi akar eksternal (ERR). Cedera juga dapat menyebabkan perubahan angi gigi sehingga harus ditangani dengan tiang dan inti yang disesuaikan untuk menghasilkan hasil estetika yang lebih baik dan untuk mendapatkan kekuatan tekan yang cukup. Laporan kasus ini menjelaskan penggunaan agregat trioksida mineral (MTA) sebagai sumbat apikal untuk mendorong penyembuhan periapikal pada apeks terbuka dan penggunaan tiang dan inti cor khusus untuk memperbaiki angulasi gigi. Laporan kasus. Seorang pasien laki-laki berusia 23 tahun datang ke RSGM Prof. Soedomo dengan keluhan utama retak dan labial yang tidak sejajar dengan gigi insisivus kanan atas karena trauma 10 tahun yang lalu. Pasien menyatakan keengganannya untuk mendapatkan terapi ortodontik. Uji perkusi dan palpasi tidak menunjukkan ketidaknyamanan atau rasa sakit. Tidak ada mobilitas yang diperhatikan. Radiograf menunjukkan radiolusen periapikal dan apeks terbuka. Gigi diobati dengan saus kalsium hidroksida dan sumbat apikal MTA ditempatkan di bagian apikal kanal. Gigi dipulihkan dengan tiang dan inti cor khusus untuk memperbaiki angulasi diikuti dengan penempatan mahkota porselen. MTA dapat digunakan sebagai plug apikal untuk menyegel apex terbuka yang disebabkan oleh ERR yang dikombinasikan dengan tiang dan inti cor khusus untuk pilihan lain untuk gigi yang tidak sejajar.
\end{abstract}

Kata Kunci: Agregat trioksida mineral; Custom cast post and core; Pergantian gigi berubah Resorpsi akar eksternal.

\begin{abstract}
Crown fracture is the most commonly reported traumatic injuries in the permanent dentition. One of the unfavorable response to trauma is the development of external root resorption (ERR). Injuries may also cause tooth angulation changes so it should be treated with a customized cast post and core to produce better aesthetic result and to obtain sufficient compressive strength. The case report describes the use of mineral trioxide aggregate (MTA) as an apical plug to promote periapical healing of an open apex and the use of custom cast post and core to correct the tooth angulation. Case report.A 23-year-old male patient came to RSGM Prof. Soedomo with a chief complaint of a fractured and labial misaligned of upper right central incisor due to trauma 10 years ago. Patient expressed his unwillingness to get orthodontic therapy. Percussion and palpation test showed no discomfort or pain. There was no mobility noticed. Radiograph showed periapical radiolucency and open apex. Tooth was treated with calcium hydroxide dressing and MTA apical plugs were placed in the apical portion of canals. Tooth was restored with custom cast post and core to correct the angulation followed by the placement of an porcelain crown. MTA can be used as apical plug for sealing open apex caused by ERR combined with custom cast post and core for other option for misaligned tooth.
\end{abstract}

Keywords: Custom cast post and core; External root resorption; Mineral trioxide aggregate; Tooth angulation changing. 


\section{INTRODUCTION}

Crown fracture is the most commonly reported dental injuries and the highest percentage of all traumatic injuries in the permanent dentition. One of the unfavorable response to trauma is the development of external root resorption (ERR) as a result of a long-standing infected root canal system. External root resorption is an irreversible loss of external tooth structure. Its etiology is multifactorial, but in many aspects remain unclear. Periapical inflammation sustained by infection can cause apical root resorption in permanent teeth. The infection may be asymptomatic for many years, althoughit is rarely misdiagnosed. Treatment of such lesions should include use of intracanal medicaments for complete debridement of the microbes

The conventional therapy of dental injury of a tooth with root resorption includes the use of calcium hydroxide in an attempt to stop the inflammatory root resorption and formation of a hard tissue apical barrier. Neverthless, the use of calcium hydroxide has a negative aspect, such as the possibility of increased root fracture. Recently, mineral trioxide aggregate (MTA) has been suggested for use as an apical plug to promote periapical healing of an open apex. MTA is composed of calcium, silica, and bismuth. It has a long setting time, high $\mathrm{pH}$, and low compressive strength. It possesses some antibacterial and antifungal properties, depending on its powder-to-liquid ratio. MTA also has good sealing ability, biocompatibility, and low cytotoxicity with a $\mathrm{pH}$ of 12,5 and sets in the presence of moisture in approximately four hours. Although properties of MTA are well described in the literature, MTA has not been employed very frequently in the treatment of external root resoption. The following case report demonstrated nonsurgical pulp space therapy of severe external root resorption and the use of MTA as an apical plug to promote periapical healing of an open apex combined with custom cast post and core restoration

\section{Case}

An 23-year old male patient came to the postgraduate clinic of the Department of End- odontic on RSGM Prof Soedomo, Gadjah Mada University, Yogyakarta, Indonesia for continuing treatment of a traumatic injury of his permanent maxillary right central incisor. The patient's chief complaint was an unaesthetic of labially misaligned fractured crown of maxillary right central incisor caused by traumatic injury 10 years ago (Figure 1 and 2 ).

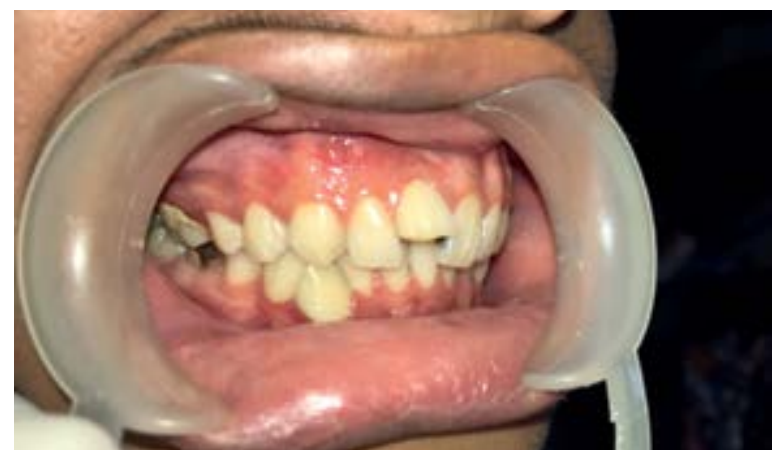

Figure 1

Labially misaligned crown fracture due to mechanical trauma taken from the right side

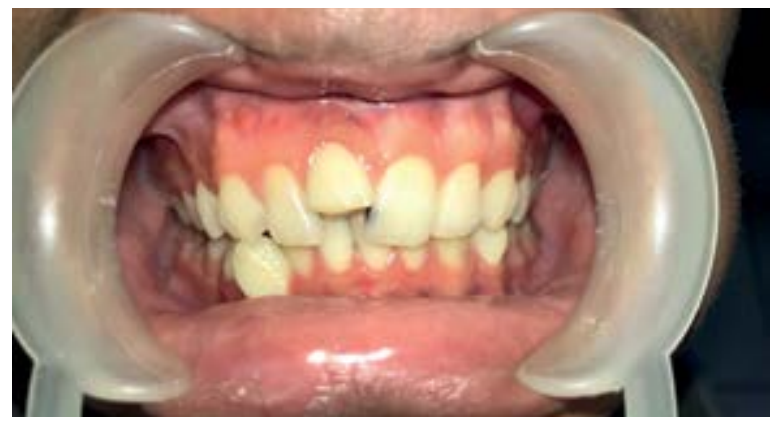

Figure 2

Labially misaligned crown fracture due to mechanical trauma taken from the front side

His medical history was non-contributory. Clinical examinations revealed labially misaligned of maxillary right central incisor. Percussion and palpation test showed no discomfort or pain. There was no mobility noticed. On radiographic examination (Figure 3) showed periapical radiolucency and progressive inflammatory external root resorption on the external apical surface of the root of maxillary right central incisor and open root apex was found. From both the clinical and radiographic examinations, the diagnosis was made as chronic apical periodontitis with apical opening caused by external root resorption 
in 11. Taking into consideration the extent and the severity of the resorption, it was planned for orthograde MTA obturation of the canal space to arrest the resorption and treatment for unaesthetic misalignment tooth.

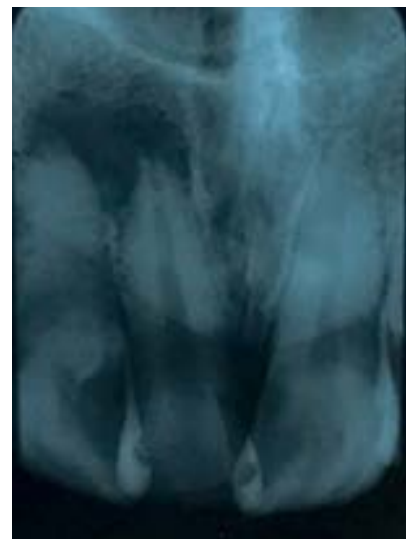

Figure 3

Radiographic examination showed periapical radiolucency and progressive inflammatory external root resorption on the external apical surface of the root of maxillary right central incisor and open root apex.

\section{Case Management}

The tooth were isolated and an access cavity was made, working length was established with help of apex locator, Propex-pixi (Dentsply) and Step-back preparation technique was performed with K-files (Maillefer Dentsply, Baillaigues, Switzerland). Canal was irrigated copiously with 5,25\% sodium hypochlorite and followed by irrigation with normal saline to remove any remnants of hypochlorite, canal was dried with absorbents points and calcium hydroxide (Ultradent) as an intracanal medicament was placed in canal followed by a temporary restorations for 1 week. This procedure was repeated three times. After 3 weeks, temporary restorations were removed, canal was cleaned and dried. MTA, pro-Root MTA (Dentsply, Tulsa Switzerland) was manipulated with sterile water in a 3:1 powder to liquid ratio according to manufacture instructions. The canal was obturated with MTA on the 5 $\mathrm{mm}$ apical portion of the canal. Material was placed in the canals and condensed vertically with hand pluggers (Figure 4).

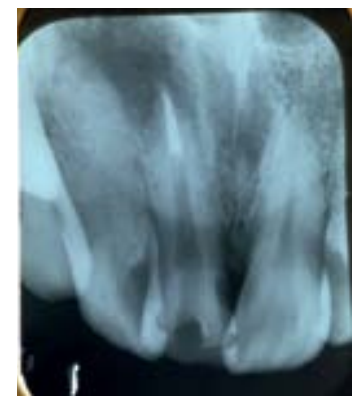

Figure 4

The canal was obturated with MTA on the $5 \mathrm{~mm}$ apical portion of the canal. Material was placed in the canals and condensed vertically to make an apical plug to close the open apex.

After completion of apical sealing using MTA, postendodontic restoration was prepared. The remaining tooth structure was prepared with shoulder finish line on labial side and chamfer on the palatal side. The length of the post was determined from periapical radiograph and peeso reamer was used to prepare the postspace. The custom dowel post and core was made by impress the postspace using polyvinylsiloxane double impression material (Exaflex, GC, Japan) to produce an accurate dental cast. Cast is poured with type IV dental stone to make a pattern for postspace. The pattern then was invested and a metal singleunit cast post and core can thus be fabricated out of orden. The core was design to change the angulation of the misalignment tooth into the appropriate inclination (Figure 5). Over the cast core, lithium disilicate crown was placed to make an aesthetic restoration (Figure 7).

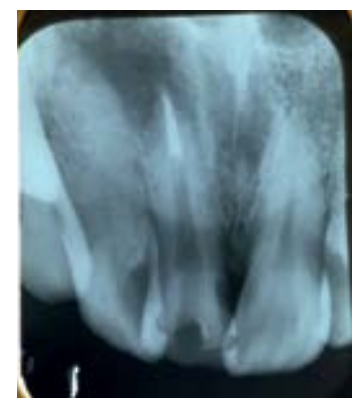

Figure 5

Custom cast post and core was made with the specific design to change the angulation of the misalignment tooth into the appropriate inclination. 


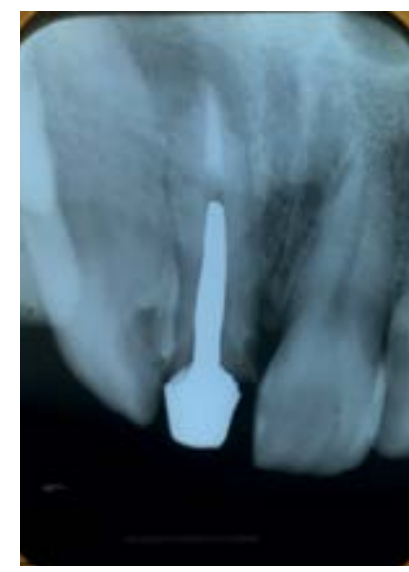

Figure 6

The aesthetic restoration made from lithium disilicate crown added with gingival color on the cervical region to enhance the aesthetic result (front side)

\section{RESULT AND DISCUSSION}

External root resorption is a pathologic condition caused by several etiological factors, such as inflammatory response that is initiated by mechanical trauma. When the endodontic treatment is delayed, pulpal infection associated with periodontal ligament damage may result in the progression of inflammatory external resorption. The presence of bacteria and their by-products inside the root canal system and dentinal tubules after pulp necrosis and in the absence of protection of cementum barriers may lead to root resorption. Resorption of the mineralized strucutres of the teeth is carried out by the multinucleated resorbing cells called odontoclasts. Treatment protocol for an external root resorption should involve elimination of bacteria and their products from root canal system to stop the inflammatory processes involving the root surface to allow the regeneration of periodontium. The major challenges in endodontic treatment of teeth with open apices due to resorption are achieving complete debridement, canal disinfection, and optimal sealing the goal of endodontic treatment is to form an apical stop on the third apical portion of the root to achieve apical barrier and avoiding over extrusion.

Recently mineral trioxide aggregate (MTA) has been recomended for various uses in endodontics due to its good sealing ability, antibacterial activity, and biocompatibility. It also encourages regeneration of peri-radicular tissues such as periodontal ligament bone and cementum. In the present case, there was severe inflammatory extrenal resorption in the apical portions of the root associated with periapical pathology that cause apical opening. After chemomechanical preparation of the root canal system, calcium hydroxide dressing was placed to provide an alkaline $\mathrm{pH}$ inside the dentinal tubules to kill the bacteria and neutralize the endotoxins, which are potent inflammatory stimulators.

As the tooth has an apical opening due to external resorption, treating it by MTA as an apical plug can also cause release of calcium ions through dentinal tubules into external resorption defect. In the case described here, 3 month radiographic recall showed osseous repair of periapical pathosis (Figure 6). The patient was asymptomatic and no mobility noticed. Custom cast post and core was used combined with the MTA apical plug because the need of angulation changing of the misalignment tooth. Custom cast post and core is a single assembly in which core can be shaped until satisfactory aesthetic is achieved although the core might not be in the same axis as the post. Figure 7. showed the aesthetic restoration made from lithium disilicate crown added with gingival color on the cervical region to enhance the aesthetic result.

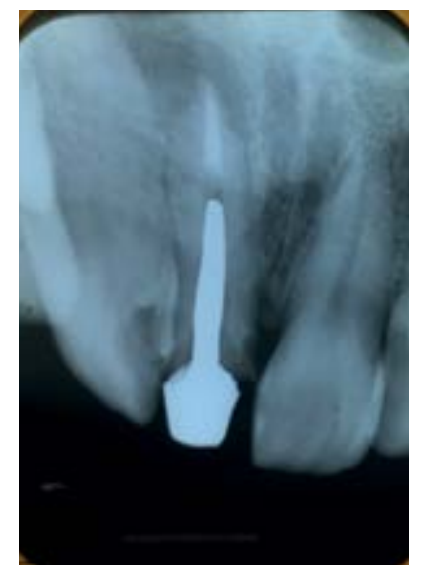

Figure 7

Three month radiographic recall showed osseous repair of periapical pathosis. The patient was asymptomatic and no mobility noticed. 


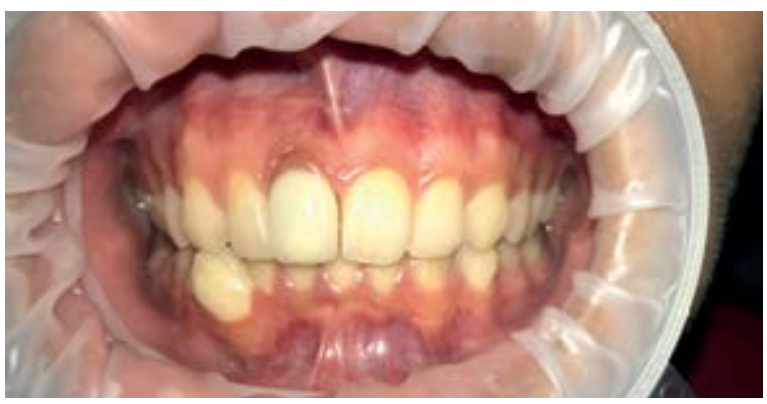

Figure 8

The aesthetic restoration made from lithium disilicate crown added with gingival color on the cervical region to enhance the aesthetic result (front side)

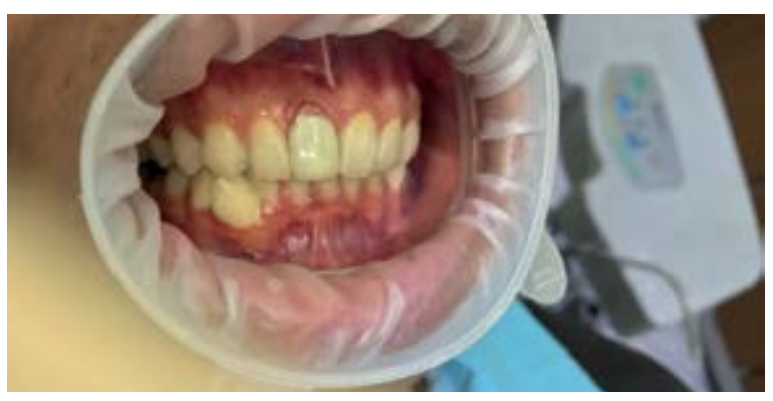

Figure 9.

The aesthetic restoration made from lithium disilicate crown added with gingival color on the cervical region to enhance the aesthetic result (right side).

\section{CONCLUSIONS}

MTA can be used as an apical plug for sealing apical opening of the root canal caused by External Root Resorption combined with custom cast post and core and lithium disilicate aesthetic restoration for treating misaligned tooth.

\section{BIBLIOGRAPHY}

Nayak MT, Nayak A. External inflammatory root resorption in mandibular first molar : a case report. Malays J Med Sci. 2015;22(6): 63-66. [Journal Article]

Andreasen JO, Farik B, Munksgaard EC. Long-term calcium hydroxide as a root canal dressing may increase risk of root fracture. Dental Traumatology. 2002;18(3) 134-137. [Journal Article]
Sharifi R, Parirokh M, Satvati SAR, Torabinejad $M$. Treatment of in inflammatory root resorption using mineral trioxide aggregate: A case report. Dental Hypotheses. 2014;5(4):172174. [Journal Article]

Parirokh M, Torabinejad M. Mineral trioxide aggregate: A comprehensive literature review-partI: chemical, physical, and antibacterial properties. J Endod, 2010;36:16-27. [Journal Article]

Torabinejad M, Parirokh M. Mineral trioxide aggregate: A comprehensive literature review-partII: chemical, physical, and antibacterial properties. J Endod, 2010;36:16-27. [Journal Article]

Agrawal VS, Kapoor S. Clinical management of severe external root resorption and immature open apex with MTA and calcium hydroxide, A case report. Endodontology. 83 - 88. Available from: http://medind.nic.in/eaa/ t11/i2/eaat11i2p81.pdf accessed on 8.7.2017. [Website]

Utneja S, Garg G, Arora S, Talwar S. Nonsurgical endodontic retreatment of advanced inflammatory external root resorption using mineral trioxide aggregate obturation. Case Rep Dent 2012. [Journal Article].

Levin L, Trope M. Root resorption in dental pulp, K. Hargreaves and H Goodis, Eds., pp. 425-448. St. Louis : Elsevier, 2002. [Book]

Raldi DP, Mello I, Habitante SM, LageMarques JL, Coil J. Treatment options for teeth with open apices and apical periodontitis. J Can Dent Assoc. 2009;75:591-6. [Journal Article]

Raut AW, Mantri VR, Palekar AU, Kamat S. Single step apexification with Mineral Trioxide Aggregate (MTA)Case Reports. NJDSR. 2012;1:28-2. [Journal Article] 
Cehreli ZC, Sara S, Uysal S, Turgut MD. MTA apical plugs in the treatment of traumatized immature teeth with large periapical lesions. Dent Traumatol. 2011;27:59-2. [Journal Article]

Mohammadi Z, Yazdizadeh M, Khademi A. Sealing ability of MTA and a new root filling material. Clin Pesg Odontol Curtitiba. 2006;2:367-71. [Journal Article]
Fuss, Z., Tsesis I, Lin S., Root resorption diagnosis, classification and treatment choices based on stimulation factors, Dental Traumatollgy (19)4: 175-182, 2003. [Journal Article]

Singh K, Kumar N, Choudhary N, Gupta $\mathrm{N}$. Unconventional prosthodontics for aesthetic rehabilitation of discoloured rotated maxillary central incisor. BMJ Case Rep 2013,1-3. [Journal Article] 